\title{
The premium on acquisition in South African mergers: An empirical evaluation
}

\author{
J.F. Affleck-Graves, G.H. Burt and S.J. M. Cleasby \\ Graduate School of Business, University of Cape Town, Private Bag, Rondebosch, 7700 Republic of South Africa
}

Accepted 3 June 1988

\begin{abstract}
In this paper both the premium paid on acquisition during a merger as well as the method by which the target companies stockholders are paid for their holding are examined. The results indicate that in the South African (S.A.) context the average premium paid on acquisition is of the order of $30-40 \%$ which is approximately the same as that paid on other major exchanges. Efforts to determine those accounting and market-related variables which were highly correlated with the premium on acquisition were relatively unsuccessful with only the price/ earnings ratio (and, to a lesser extent relative size) being significantly correlated with the premium. In both cases, the correlations were positive, indicating that a higher $\mathrm{P} / \mathrm{E}$ ratio in the target company and/or a target company which is large relative to the acquirer will result in a higher premium on acquisition. Finally, the results indicate that a cash payment remains the most popular method of payment in South African mergers, followed by an equity swap. These results appear to be time independent.
\end{abstract}

\begin{abstract}
In hicrdie artikel word die premie wat op oorneming gedurende 'n samesmelting betaal word, asook die metode waardeur die oorgenome maatskappye se aandeelhouers betaal word vir hulle aandele, ondersoek. Die resultate dui aan dat in die Suid-Afrikaanse verband die gemiddelde premie wat op oorneming betaal word ongeveer $30-40 \%$ is, wat ongeveer dieselfde is as dic wat op ander groot effektebeurse betaal word. Pogings om die rekening- en markverwante veranderlikes wat hoër korrelasies met die premic op oorneming getoon het te bepaal was betreklik onsuksesvol, met net die prysverdienste $(\mathrm{P} / \mathrm{E})$-verhouding (en, in ' $\mathrm{n}$ kleiner mate, betreklike grootte) wat in betekenisvolle korrelasic met die premie toon. In albei gevalle is die korrelasies positief, wat aandui dat ' $\mathrm{n}$ hoër $\mathrm{P} / \mathrm{E}$-verhouding in die oorgenome maatskappy wat betreklik groot is in vergelyking met die oornemende maatskappy, tot gevolg sal hề dat 'n hoër premie op oorneming betaal word. Ten slotte, dui die resultate aan dat 'n kontantbetaling dic populêrste metode van betaling in Suid-Afrikaanse samesmeltings bly, gevolg deur 'n aandeelruiling. Dit lyk asof hierdie resultate onafhanklik van tyd is.
\end{abstract}

\section{Introduction}

The subject of mergers and acquisitions has aroused considerable interest in the recent finance literature. In particular, at least three distinct areas of research have emerged, namely the benefits accruing to the stockholders of both the acquired and the acquiring companies around the time of the merger announcement, the long-term benefits accruing to the shareholders of the acquiring companies (especially in the case of conglomerate companies), and finally, the study of tender offers made during takeover bids. The first two areas have been examined in the South African context by Affleck-Graves, Flach \& Jacobson (1987) and Affleck-Graves, Burt \& Cleasby (1987), respectively. This study focuses on the third aspect, namely the offer made by the acquiring company to the stockholders of the target (or acquired) company.

In examining the premium paid on acquisition for a sample of South African mergers, this paper has three specific objectives. Firstly, an attempt is made to determine the average premium paid on acquisition in South African mergers. Secondly, the method by which payment was made (e.g., cash, equity in the merged company, or debt) was examined in order to determine the extent to which each of these methods has been used in the South African capital markets and also to determine whether the predominant method of financing has changed over time. Finally, using correlation analysis, an attempt was made to determine those accounting and market-determined measures which might best explain the magnitude of the premium paid on acquisition.

\section{Background}

For the purposes of this paper. a tender offer is defined as a cash or stock (or some other) bid by one company (the acquirer) for a controlling interest in another company (the target or acquired company). It is presumed that the offer is made on the assumption that some form of synergy or other benefit will result from the merging of the two firms into one. In the usual notation of the merger literature, this is written as:

$V_{A B}>V_{A}+V_{B}$

where $V_{A B}=$ value of the merged firm after the merger, $V_{A}=$ value of firm $A$ prior to the merger, and $V_{B}=$ value of firm $B$ prior to the merger.

In other words, it is assumed that the merger will add value with the combined firm being worth more than the sum of the two individual firms.

Given that firms only merge because of anticipated value creation, the logical question is who receives the benefits of this value creation? As Brealey \& Myers (1985) pointed out, this can be examined by defining the overall gain $\left(G_{o}\right)$ from the merger as.

$G_{o}=V_{A B}-\left(V_{\mathrm{A}}+V_{\mathrm{B}}\right)$

Clearly this gain must be divided between the stockholders of the acquiring company and the stockholders of the target company. In particular, the benefit to the stockholders of the target company can be written as: 
$G_{T}=P P-V_{B}$

where $P P=$ the price paid to the stockholders of the acquired company.

Clearly, $G_{T}$ is what is commonly known as the premium on acquisition if it is assumed that $V_{B}$ equals the market value of the equity in the target company prior to the merger bid. Consequently, $G_{T}$ is the variable which is the focus of attention in this study. (Note that $G_{o}-G_{7}$ provides a measure of the benefit of the merger to the stockholders of the acquiring company.)

Jensen \& Ruback (1983) have provided a comprehensive survey of the U.S. research on mergers and acquisitions. Additional summaries can be found in advanced finance texts such as Copeland \& Weston (1983). Of particular interest in the Jensen \& Ruback survey is the emphasis they place on merger and acquisitions being seen as competition in the market for corporate control. Thus, they view the market for corporate control as a market in which alternative managerial teams compete for the right to manage corporate resources. This implies that the takeover market is an important component of the managerial labour market which in turn limits the diversion of wealth from stockholders through managers' merger activity. Also, it follows from this assumption that, overall, mergers must have positive net present value.

In surveying the wealth effects of takeover activity, Jensen \& Ruback summarize most of the relevant literature (e.g. Dodd \& Ruback, 1977; Kummer \& Hoffmeister, 1971; Dodd, 1980; Bradley, 1980; Bradley, Desai \& Kim, 1982, 1983; Asquith, 1983; Eckbo, 1983; and Malatesta, 1983). Their overall conclusion is that stockholders of both the acquiring and the target companies gain from merger activity. In particular, they conclude that the stockholders of the target firms earn abnormal returns averaging approximately $29 \%$. Also, the stockholders of the bidding firms generally earn significant but small $(2-7 \%)$ abnormal returns in the case of tender offers but do not earn abnormal returns significantly different from zero in mergers (they distinguish between tender offers which are made directly to the target stockholders and mergers where the negotiations are carried out with the target companies' management before the latter approach the ordinary stockholders for approval).

The above studies all deal with merger activity on the major U.S. exchanges. Firth (1979) performed similar tests on the United Kingdom (U.K.) market and found that the target companies stockholders earned abnormal returns of about $38 \%$. The stockholders of the acquiring firms had small positive abnormal returns prior to the announcement but negative abnormal returns of $4,5 \%$ within 24 months of the offer.

The studies reviewed above all used abnormal return (Fama, Fisher, Jensen \& Roll, 1969) as the unit of measure. As such they focus on share price movements around the date of the merger announcement. Since the acquiring company is frequently much larger than that of the target firm, it is not surprising that greater share price impact is seen in the target company group. Several authors have recently focused on the total dollar value associated with takeovers. For example, Malatesta (1983) and Bradley, Desai \& Kim (1982) both reported significant overall gains from merger activity. However, they were unable to find any significant difference in the split of these gains between the target and the acquiring companies.

Stock market gains to the stockholders of either the target company or the acquiring company or both were the focus of the above studies. As such, they are not a real measure of the premium on acquisition since they do not take into account any details of the actual offer made by the acquiring company. This is exemplified in Bradley (1980) who found that the mean premium paid in 161 successful tender offers was $49 \%$ even though the market price of the target shares reflected only a $36 \%$ average increase over their pre-announcement value. This is similar to the average premium of $50 \%$ for U.S. companies cited by Copeland \& Weston (1983: 564).

To date, relatively few studies on merger activity have appeared in the S. A. literature. Of the few that have appeared, both Bhana (1984) and Smullen (1970) have examined the method of financing rather than the premium on acquisition or the benefits to either set of stockholders. Affleck-Graves, Flach \& Jacobson (1987) examined the short-term effects of mergers in terms of abnormal price performance. They found that stockholders of the target companies earned substantial positive abnormal returns $(20 \%)$ in the 13 weeks prior to the merger announcement. However, they found no evidence of abnormal returns accruing to the stockholders of the acquiring companies. However, Affleck-Graves, et al. do not comment on the premium on acquisition paid in their sample of mergers. Finally, Affleck-Graves, Burt \& Cleasby (1987) examined the long-term profitability of conglomerates in South Africa. As they concentrated only on long-term effects, their study did not have any implications regarding the premium on acquisition.

\section{Methodology and Data}

In this study, three basic issues are addressed. Firstly, an attempt is made to estimate the average premium paid on acquisition over the period January, 1976 December, 1984. Secondly, the method of financing mergers and acquisitions over this period is examined both by comparing the methods used in this period with the results obtained in earlier studies as well as by comparing the financing methods utilized on a year-toyear basis within the study period. Finally, an attempt is made using correlation analysis to determine those accounting and market-related variables which best explain the magnitude of the premium on acquisition.

The basic data for the study were obtained from the JSE Monthly Bulletin (December, 1984). This bulletin contained information on 137 mergers and acquisitions over the period $1976-1984$. However, only 64 mergers could be used for the first and third analyses because of the lack of either stock market data or the required financial data. 
A major problem in any study of the premium on acquisition is the ex post measurement of the exact magnitude of the premium paid. As has been welldocumented in studies in both the U.S. (Jensen \& Ruback, 1983) and South Africa (Affleck-Graves, Flach \& Jacobson, 1987), the stockholders in the target companies experience, on average, highly positive abnormal returns prior to the announcement of the takeover or merger. Whether this is due to anticipation, leakages, insider trading or some other factor is unknown, but the fact remains that such positive abnormal returns are experienced for up to six months prior to the merger announcement. Consequently, it is obvious that some of the merger information is already impounded in the price (either as a result of leakages, insider trading or anticipation) and hence it is not sufficient to assume that the premium on acquisition is simply the difference between the offer price and the quoted price of the stock immediately prior to the announcement of the merger.

As a result of the above and because there is uncertainty as to exactly how long before the announcement information may be reaching the market, the following approach was adopted in estimating the premium on acquisitions paid in each of the 64 mergers examined in this study. In order to ensure that the initial price is not affected by leakages, the initial price was fixed at the market price of the target company exactly one year prior to the date on which the company's listing on the JSE was withdrawn. This share price was then adjusted by calculating the return that would reasonably have been expected from the firm in the absence of the takeover offer, given the actual market conditions that arose in the year. This was computed using the wellknown Capital Asset Pricing Model (CAPM) (Sharpe, 1964; Lintner, 1965; Mossin, 1966) as follows:

$E R_{i}=R_{F}+\beta_{s}\left(R_{M}-R_{F}\right)$

where $E R_{i}=$ the return that would have been expected from target company $i$ in the year prior to the takeover; $R_{F}=$ the risk-free rate (taken as the three-month Treasury Bill rate); $\beta_{s}=$ the beta coefficient for the sector in which the acquired firm was quoted on the JSE; $R_{m}=$ the return on the market (as measured by the JSE Actuaries Industrial Index) in the year of the delisting of the acquired company.

The required estimates of $\beta_{s}$ for the relevant sectors of the JSE were acquired from the published $\beta_{\mathrm{s}}$ of McKie Bros., Van Zelden, Channing \& Mennie (1984).

The expected share price, in the absence of a takeover bid, for the acquired company was then calculated as:

$E P_{i}=\left(1+E R_{i}\right)^{*} S P_{i, t-1}$

where $E P_{i}=$ the expected share price of company $i$ on the date of delisting, assuming no takeover bid had been made; and $S P_{i, 1-1}=$ the share price of company $i$ one year prior to delisting.

Using this $E P_{i}$, the premium on acquisition can be computed in percentage terms as:
$P A_{i}=\frac{A P_{i}-E P_{i}}{E P_{i}} * 100$

where $A P_{i}=$ the actual price per share paid in terms of the takeover bid; and $P A_{i}=$ the percentage premium paid on acquisition for company $i$.

The second aspect of the study involved an examination of the method of financing used in mergers in South Africa over the period 1976-1984. Each of the 137 mergers listed in the JSE Monthly Bulletin (1984) was examined and the method of financing classified into one of the following groups:

(i) Cash only;

(ii) Equity capital only;

(iii) Debt and preference shares only;

(iv) Combination of the above;

(v) Other methods.

These are the same categories used by Smullen (1974) and Bhana (1984) which allows comparisons to be made. The number of mergers in each of the above categories were then counted for the period January, 1976 December, 1984. In addition, each of the years 1976 1984 were analyzed separately in terms of the same categories to ascertain whether there were any clear trends in the methods of financing used over the period examined.

The final aspect of this study deals with a correlation analysis in an attempt to determine those accounting and market-related variables which best predict the premium on acquisition (as calculated in the first part of this study). The following 10 accounting and market-related variables were examined as possible predictors of premium on acquisition.

- price earnings ratio

- earnings per share

- return on assets

- return on equity

- cash

- net worth (net asset value per share)

- Debt Equity Ratio (DER)

- debt ratio

- absolute value of the difference between the DER of the acquiring company and the DER of the acquired company

- ratio of total assets of the acquired company to that of the acquiring company

The Pearson Product Moment Correlation between each of these variables and the premium on acquisition was calculated using the 64 mergers identified in the first part of this study. The significance of each of the 10 correlation coefficients was examined using the familiar $t$ test (Lehman, 1985: 394).

\section{Results}

For each of the 64 acquisitions identified in the previous section, the percentage premium on acquisition was estimated using equation (1). These 64 percentage premiums on acquisition were then averaged to determine the average percentage premium on acquisition paid by companies listed on the JSE. The 
Table 1 Average premium on acquisition

\begin{tabular}{lcc}
\hline Measure & \multicolumn{2}{c}{$\begin{array}{c}\text { Average Premium } \\
\text { Paid (\%) }\end{array}$} \\
\hline Geometric Mean & Exchange & 31,7 \\
Arithmetic Mean & JSE & 43,6 \\
Median & JSE & 33,7 \\
Median (Shad. 1969) & JSE & 20 \\
A. Mean (Brozen, 1982) & NYSE & 50 \\
A. Mean (Newbould, 1970) & NYSE & 45,1 \\
\hline
\end{tabular}

results are summarized in Table 1 together with summary results from two non-South African studies.

Table 1 provides three estimates of the typical percentage premium on acquisition paid, namely the geometric mean, the arithmetic mean and the median. As is well known, the geometric mean will always be less than or equal to the arithmetic mean and thus provides a measure of the lowest possible mean from the family of mean-type estimators. It, therefore, indicates a floor or lowest possible estimate of the average premium on acquisition. In addition, the median is presented as the arithmetic mean is likely to be skewed by very large values. Our results indicate that the geometric mean is $31,7 \%$ which implies that the average premium on acquisition is at least $31,7 \%$. The arithmetic mean of $43,6 \%$ is considerably larger indicating the probable presence of a few unusually large premiums in the sample of 64 . This is confirmed by the median of $33,7 \%$.

It is, therefore, concluded that the average premium on acquisition paid by companies listed on the JSE is between $32 \%$ and $44 \%$ with half of the mergers yielding premiums greater than $34 \%$ and half yielding premiums less than $34 \%$. This is somewhat higher than the median of $20 \%$ found by Shad (1969) in a study of U.S. mergers. However, it is lower than the $50 \%$ mean found by Brogen (1982:40) in a study of U.S premiums during 1979. It is also slightly lower than the $45,1 \%$ mean found by Newbould (1970:55) in a study of U.K. mergers over the period $1967-1968$. Thus, the latter two studies do indicate that the mean premium paid in S. A. is not likely to be markedly different from that paid in other welldeveloped counties.
Table 2 Distribution of different methods of financing

\begin{tabular}{|c|c|c|c|c|}
\hline \multirow{2}{*}{$\begin{array}{l}\text { Method of } \\
\text { Financing }\end{array}$} & \multicolumn{2}{|c|}{$\begin{array}{c}\text { Current Study } \\
1976-1984\end{array}$} & \multirow{2}{*}{$\begin{array}{c}\text { Bhana Study } \\
1966-1976 \\
\%\end{array}$} & \multirow{2}{*}{$\begin{array}{c}\text { Smullen Study } \\
\text { 1966-1969 } \\
\%\end{array}$} \\
\hline & Actual \# & $\%$ & & \\
\hline Cash only & 60 & 43,8 & 37,0 & 40,0 \\
\hline Equity only & 38 & 27,7 & 30,0 & 31,0 \\
\hline $\begin{array}{l}\text { Debt \& Pref. } \\
\text { Shares }\end{array}$ & 5 & 3,7 & 2,1 & 2,5 \\
\hline Combinations & 34 & 24,8 & 30,6 & 25,9 \\
\hline Other & - & - & - & 0,5 \\
\hline Total & 137 & 100 & 100 & 100 \\
\hline
\end{tabular}

The second aspect of this study deals with the method used to finance the acquisition. The 137 acquisitions examined in this study were examined to establish the principal method of payment used by the acquiring company. These results are presented in Table 2 which also summarizes the results of two earlier South African studies.

As can be seen from Table 2, cash was the most popular method of payment during the period 1976 1984. Equity capital was the second most popular method of payment followed by a combination of cash, equity and/or debt, and preference shares. The use of debt and/or preference shares was the least popular method. These rankings are identical to those obtained by Bhana (1984) for the period 1966 - 1976. In addition, tests of the difference between the percentages obtained in the Bhana study and the percentages obtained in this study were not statistically significant at the $5 \%$ level.

The results from the Smullen study are for an overlapping period and are thus not independent of the Bhana study. Once again, no statistically significant differences were found between the Smullen group and either the Bhana or the current study.

To examine whether the method of financing has remained constant over the period examined, the 137 acquisitions are examined on a year-by-year basis. The results are summarized (in percentage form) in Table 3.

Table 3 shows that, for example, of the 25 acquisitions in $1976,24 \%$ (or 6 ) were financed by means of a cash payment. Table 3 can be further analyzed by testing

Table 3 Annual distribution of methods of financing

\begin{tabular}{|c|c|c|c|c|c|c|c|c|c|c|c|c|c|c|c|c|c|c|}
\hline \multirow{2}{*}{$\begin{array}{l}\text { Method of } \\
\text { financing }\end{array}$} & \multicolumn{2}{|c|}{1976} & \multicolumn{2}{|c|}{1977} & \multicolumn{2}{|c|}{1978} & \multicolumn{2}{|c|}{1979} & \multicolumn{2}{|c|}{1980} & \multicolumn{2}{|c|}{1981} & \multicolumn{2}{|c|}{1982} & \multicolumn{2}{|c|}{1983} & \multicolumn{2}{|c|}{1984} \\
\hline & $\#$ & $\%$ & $\#$ & $\%$ & \# & $\%$ & $\#$ & $\%$ & \# & $\%$ & $\#$ & $\%$ & \# & $\%$ & $\#$ & $\%$ & $\#$ & $\%$ \\
\hline Cash & 6 & 24 & 11 & 58 & 16 & 62 & 5 & 83 & 4 & 29 & 7 & 39 & 4 & 36 & 5 & 50 & 2 & 25 \\
\hline Equity & 12 & 48 & 5 & 26 & 3 & 12 & 0 & 0 & 4 & 29 & 5 & 28 & 3 & 27 & 3 & 30 & 3 & 38 \\
\hline Debt. \& Pref. & 1 & 4 & 0 & 0 & 2 & 8 & 1 & 17 & 1 & 7 & 0 & 0 & 0 & 0 & 0 & 0 & 0 & 0 \\
\hline \multirow[t]{2}{*}{ Combinations } & 6 & 24 & 3 & 16 & 5 & 19 & 0 & 0 & 5 & 36 & 6 & 33 & 4 & 36 & 2 & 20 & 3 & 38 \\
\hline & 25 & & 19 & & 26 & & 6 & & 14 & & 18 & & 11 & & 10 & & 8 & \\
\hline
\end{tabular}

$x^{2}=28,31$ (calculated; $x^{2} 24: 0.05=36,4$ (from tables) 
whether the method of financing is independent of the year. Since the data used in constructing Table 3 were count data, this can be done using the $\chi^{2}$ contingency table test (Lehman, 1985:383). The test statistic at the base of Table 3 indicates that the null hypothesis of independence between method of financing and year cannot be rejected, even at the $10 \%$ level of significance. Thus, it is concluded that the method of finance is independent of time which would imply that it is relatively unaffected by the phase of the business cycle.

The final aspect of this study involves a correlation analysis of the premium on acquisition and ten accounting and market-related variables. The results are summarized in Table 4.

Table 4 Correlations with premium on acquisition

\begin{tabular}{|c|c|c|c|}
\hline Variable & $\begin{array}{l}\text { Correlation } \\
\text { with premium }\end{array}$ & $\begin{array}{c}\text { Percentage variation } \\
\text { explained by the } \\
\text { variable }(\%)\end{array}$ & $t$ value \\
\hline $\begin{array}{l}\text { Price earnings } \\
\text { ratio }\end{array}$ & 0,3300 & 10,9 & 2,75 \\
\hline $\begin{array}{l}\text { Earnings per } \\
\text { share }\end{array}$ & 0,0340 & 0,1 & 0,27 \\
\hline $\begin{array}{l}\text { Return on } \\
\text { assets }\end{array}$ & $-0,1680$ & 2,8 & $-1,34$ \\
\hline $\begin{array}{l}\text { Cash/total } \\
\text { assets }\end{array}$ & $-0,1810$ & 3,3 & $-1,45$ \\
\hline $\begin{array}{l}\text { Net asset value } \\
\text { per share }\end{array}$ & 0,0160 & 0,03 & 0,13 \\
\hline Return on equity & $-0,0795$ & 0,6 & $-0,63$ \\
\hline $\begin{array}{l}\text { Debt-Equity } \\
\text { ratio }\end{array}$ & $-0,0313$ & 0,1 & $-0,25$ \\
\hline DER differences & $-0,0794$ & 0,6 & $-0,63$ \\
\hline Debt ratio & $-0,0311$ & 0,1 & 0,24 \\
\hline $\begin{array}{l}\text { Relative asset } \\
\text { size }\end{array}$ & 0,2200 & 4,7 & 1,78 \\
\hline
\end{tabular}

As can be seen from the table, only the price/earnings ratio is significantly correlated with the percentage premium paid (at the $5 \%$ level of significance). The correlation coefficient in this case was positive which indicates that higher premiums are paid, on average, for companies with above average $\mathrm{P} / \mathrm{E}$ ratios than are paid for companies with below average $\mathrm{P} / \mathrm{E}$ ratios. Whether this is because the higher $\mathrm{P} / \mathrm{E}$ ratio companies represent growth prospects which are being acquired or because they are companies with good asset bases but passing through a phase of low earnings performance cannot be answered with the data available for this study.

Relative asset size is significantly correlated with the percentage premium on acquisition at the $10 \%$ level of significance. Once again, the correlation coefficient is positive indicating that the greater the asset size of the target company relative to the acquirer, the greater the premium that will he paid. This is consistent with the preliminary results of Scanlon, Trifts \& Pettway (1986) suggesting that size may be the key variable in explaining the abnormal profits earned by stockholders of the target firms prior to the announcement of a merger.

Finally, it is worth noting that two other variables, while not statistically significant, were relatively highly correlated with the percentage premium on acquisition (as evidenced by $t$ values $>1,25$ ). These are return on assets and cash/total assets. In both cases, the correlation coefficient is negative indicating that the higher these two ratios, the lower the premium paid on average. While economic interpretation of these results should be treated with caution (because correlation does not imply causality) it is possible that the results indicate that, on average, corporations are not acquired for either their management skills (which should be evidenced by a high return on assets) or for their cash resources (which would be evidenced by a high cash/total assets ratio). Taken in conjunction with the significant positive correlation between premium on acquisition and $P / E$ ratio, these results could indicate that corporations are acquired for reasons related to what the acquiring companies' management can do with the acquired assets rather than for the skills of the target companies' management or their historic profitability. Thus, corporations with low return on assets but good growth prospects (i.e., high $\mathrm{P} / \mathrm{E}$ ratio) attract higher premiums as do companies with low return on assets but solid asset bases which could prove more profitable in the hands of better management.

\section{Conclusions}

In this paper, the premium on acquisition paid in a takeover bid has been empirically examined for a sample of South African mergers. The results indicate that the average premium is of the order of $32-44 \%$ which is comparable to the premiums found in studies on the New York and London Stock Exchanges. From an analysis of the method of financing employed, it was concluded that a cash payment was the most popular financing method in S.A. mergers. Moreover, this did not appear to be time dependent. Therefore, while the number of mergers may increase or decrease during different phases of the business cycle, the particular phase does not appear to significantly affect the method of payment.

Finally, an attempt was made to determine the degree to which several accounting and market-related measures were related to the premium on acquisition. Only one variable ( $\mathrm{P} / \mathrm{E}$ ratio) was significantly correlated with the premium, with the sign of the correlation coefficient indicating that the higher the $\mathrm{P} / \mathrm{E}$ ratio, the greater, on average, the premium paid on acquisition. In addition, the results indicated that the aclative size of the target company, vis á vis, the acquirer, might also be an important variable. In particular, the results suggest that the larger the size of the target relative to the acquirer, the greater the premium on acquisition.

\section{Acknowledgements}

The authors wish to acknowledge the financial assistance rendered by the Human Sciences Research Council 
(HSRC) towards the costs of this research. They would also like to thank the Johannesburg Stock Exchange (JSE) for providing the share price data used in the study. Opinions expressed and conclusions drawn are those of the authors and are not to be regarded as those of either the HSRC or the JSE.

\section{References}

Affleck-Graves, J.F., Flach, T. \& Jacobson, A. 1987. The Effect of Merger Announcements on the Prices of the Acquired and Acquiring Companies. S. Afr. J. Bus. Mgmt., vol.19, 147-154.

Affleck-Graves, J.F., Burt, G. \& Cleasby, S. 1987. An Empirical Study of the Performance of South African Conglomerates: Working Paper \#87-12, Graduate School of Business, University of Cape Town.

Asquith, P. 1983. Merger Bids, Uncertainty, and Stockholder Returns. J. Finan. Econ., vol. 11, 51-83.

Bhana, N. 1984. The Long-Term Effects of Takeovers on the South African Economy. S. Afr. J. Bus. Mgmt., vol. 15, 229-231.

Bradley, M. 1980. Interfirm Tender Offers and the Market for Corporate Control. J. Bus. . vol. 53, 345-376.

Bradley, M., Desai, A. \& Kim, E.H. 1982. Specialized Resources and Competition in the Market for Corporate Control. Working Paper, University of Michigan.

Bradley, M., Desai, A. \& Kim, E.H. 1983. The Rationale Behind Interfirm Tender Offers: Information or Synergy? J. Finan. Econ., vol. 11, 183-206.

Brealey, R. \& Myers, S. 1985. Principles of Corporate Finance. New York: McGraw.Hill.

Brozen, Y. 1982. Mergers in Perspective. American Enterprise Institute, Washington.

Copeland, T.E. \& Weston, J.F. 1983. Financial Theory and Corporate Policy. Second Edition. Reading: Addison Wesley.

Dodd, P. 1980. Merger Proposals, Management Discretion and Stockholder Wealth. J. Finan. Econ., vol. 8, 105-138.

Dodd. P. \& Ruback, R. 1977. Tender Offers and Stockholder Returns: An Empirical Analysis. J. Finan. Econ., vol. 5, 351-374.
Eckbo, B.E. 1983. Horizontal Mergers, Collusion, and Stockholder Wealth. J. Finan. Econ., vol. 11, 241-273.

Fama, E.F., Fisher, L., Jensen, M.C., \& Roll. R. 1969. The Adjustment of Stock Prices to New Information. Intern. Econ. Rev., vol. 10, 1-21.

Firth, M. 1979. The Profitability of Takeovers and Mergers. Econ. J., vol. 89, 316-328.

Jensen, M.C. \& Ruback, R. 1983. The Market for Corporate Control: The Scientific Evidence. J. Finan. Econ., vol. 11, 5-50.

Johannesburg Stock Exchange. 1984. JSE Monthly Bulletin, December.

Kummer, D. \& Hoffmeister, R. 1978. Valuation Consequences of Cash Tender Offers. J. Fin., vol. 33, 505-516.

Lehmann, D. 1985. Market Research Analysis. Illinois: Richard D. Irwin.

Lintner, J. 1965. The Valuation of Risk Assets and the Selection of Risky Investments in Stock Portfolios and Capital Budgets. Rev. Econ. Stat., vol. 47, 13-37.

Malatesta, P. H. 1983. The Wealth Effect of Merger Activity and the Objective Functions of Merging Firms. J. Finan. Econ., vol. 11, 155-181.

McKie Bros., Van Zelden, Channing \& Mennie. 1984. Portfolio Risk Management.

Mossin, J. 1966. Equilibrium in a Capital Asset Market. Econometrica, vol. 34, 768-783.

Newbould, G. D. 1970. Management and Merger Activity. Liverpool: Guthstead Ltd.

Scanlon, K.P., Trifts, T.W. \& Pettway, R.H. 1986. The Returns to Shareholders of Acquiring Firms; A Study of Systematic Returns on a Disaggregated Sample. Unpublished Working Paper. University of Notre Dame.

Shad, S.R. 1969. The Financial Realities of Mergers. Harv. Bus. Rev., vol. 47, 133-146.

Sharpe, W.F. 1964. Capital Asset Prices: A Theory of Market Equilibrium Under Conditions of Risk. J. Fin., vol. 19, 425-442.

Smullen, M.D. 1970. Mergers and Management. Unpublished MBA Thesis, University of Cape Town. 